\title{
SYNTHESIS AND ANTIMICROBIAL EVALUATION OF SYMMETRICAL DIQUATERNARY AMMONIUM SALTS BEARING BIS-1,3,4-OXADIAZOLE RINGS MOIETIES
}

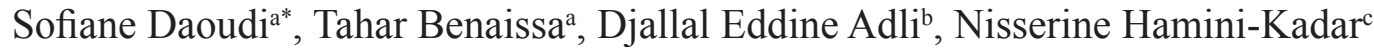 \\ ${ }^{a}$ Physical Chemistry Studies Laboratory, University of Dr. Moulay Tahar, Saïda 20000, Algeria \\ ${ }^{b}$ Department of Biology, Faculty of Sciences and Technology, University of Dr. Moulay Tahar, Saïda 20000, Algeria \\ ${ }^{c}$ Laboratory of Applied Microbiology, Department of Biology, Faculty of Nature Sciences and Life, University of Ahmed Ben Bella \\ 1.BP 16. Es-Senia 31100, Oran, Algeria \\ "e-mail: daoudi_20@yahoo.fr
}

\begin{abstract}
This study describes the synthesis of some novel compounds containing bis-1,3,4-oxadiazole bearing quaternary ammonium salt moieties. The target compounds were prepared from 2-(dimethylamino)ethyl methacrylate (DMAEMA) or 2-(diethylamino) ethyl methacrylate (DEAEMA), using adipic acid as starting material. All the newly synthesized compounds showed satisfactory analytic data for the proposed structures, which were confirmed by IR and NMR $\left({ }^{1} \mathrm{H}\right.$ and $\left.{ }^{13} \mathrm{C}\right)$ spectroscopy. The newly synthesized compounds were evaluated for their antibacterial activity against various gram-positive and gram-negative strains of bacteria, and the antifungal activities were tested against three phytopathogenic fungi namely, Fusarium oxysporum, Fusarium commune and Fusarium rodelens. Some of the tested compounds displayed promising antibacterial and antifungal activities.
\end{abstract}

Keywords: 1,3,4-oxadiazole, quaternary ammonium compounds, DMAEMA, DEAEMA, antimicrobial activities.

Received: February 2016/ Revised final: March 2016/ Accepted: March 2016

\section{Introduction}

The treatment of bacterial and fungal infectious diseases remains a challenging problem because of the increasing number of microbial pathogens [1-3]. The current interest in the development of new antimicrobial agents can be partially ascribed both to the increasing emergence of bacterial resistance to antibiotic therapy and to newly emerging pathogens [4]. It reinforces the need for the development of new and potent chemical entities or an improvement in the activity of the well-known chemical compounds. Considering this statement, the synthesis of analogues can be seen as an efficient approach to optimize an active chemical structure and design new drugs [5-8], since simple structural changes can lead to better biological activities through modifications of physicochemical properties [9].

Literature survey reveals that compounds containing 1,3,4 oxadiazole nucleus have demonstrated a wide range of pharmacological activities [10,11], including: anti-inflammatory [12], antimicrobial [13], analgesic [14], antiviral [15], antiproliferative [16], antitumor [17], antihypertensive [18,19], antioxidant [20], antitubercular [21], sedativehypnotic [22] and antibacterial and antifungal activities [23].

Quaternary ammonium salts (QAS) constitute an important class of organic compounds that are present in a large number of biologically active molecules [24]. It was reported that the quaternary ammonium compounds have antimicrobial properties [25], show adsorption on negatively charged solids, act on the cell wall and have a direct or indirect lethal effect on the cell [26]. QAS were introduced as antimicrobial agents by Domagk over eighty years ago [27].

In recent years the number of applications of QAS has been continuously increasing. They are widely used as biocides [28,29], antibiotic [30], disinfectants [31], antimalarial [32] and antimicrobial properties [33,34]. In the design of new drugs, the combination of different pharmacophores frame may lead to compounds with interesting biological profiles [35]. Also, QAS incorporating heterocycles, e.g. 1,3,4-oxadiazole, displayed various pharmacological properties [36]. Prompted by these investigations, we have synthesized compounds $\mathbf{5 a}$ and $\mathbf{5 b}$ containing bis-1,3,4oxadiazole fragment with the attached quaternary ammonium group and their antimicrobial activity has been evaluated.

\section{Materials and methods}

All solvents and reagents were obtained from Sigma Aldrich and BIOCHEM. The purity of compounds was routinely checked by thin layer chromatography (TLC) using silica gel F254 supplied by MERCK, and spots were observed using iodine as visualizing agent. uncorrected.

All melting points were determined in open capillary tubes on a BÜCHI 540 melting point apparatus and are

The IR spectra in the range of $4000-400 \mathrm{~cm}^{-1}$ were recorded as potassium bromide discs on a Shimadzu FTIR8300 spectrophotometer.

The ${ }^{1} \mathrm{H}$ and ${ }^{13} \mathrm{C}$ NMR Spectra were measured in DMSO- $d_{6}$ on a Bruker AM $300 \mathrm{MHz}$ spectrometer (University of Oran, Es-Senia), operating at $300 \mathrm{MHz}$ for ${ }^{1} \mathrm{H}$ and $75 \mathrm{MHz}$ for ${ }^{13} \mathrm{C}$ nuclei, relative to the internal standard of tetramethylsilane (TMS). Chemical shift values are expressed in parts per million $(\delta, \mathrm{ppm})$. 


\section{Preparation of diethyl adipate 2}

Diethyl adipate 2 was prepared according to the reported in the literature procedure [37]. The adipic acid (5 g, $0.034 \mathrm{~mol}$ ) was dissolved in $200 \mathrm{~mL}$ of absolute ethanol and a few drops of conc. sulphuric acid was added. The mixture was heated at $80^{\circ} \mathrm{C}$ in an oil bath for 8 hours, the progress of the reaction being monitored by TLC. After completion of the reaction, the excess of ethanol was removed under reduced pressure and the residue was extracted with chloroform. The organic layer extract was washed with a 5\% solution of sodium bicarbonate, then the solvent was evaporated and the product was collected. Yield of compound 2-76\%. Liquid, $\mathrm{R} f=0.45\left(\mathrm{CHCl}_{3} / \mathrm{CH}_{3} \mathrm{OH}=8 / 2\right) ; \mathrm{IR}\left(\mathrm{KBr}, v \mathrm{~cm}^{-1}\right): 1706.9$ $(\mathrm{C}=\mathrm{O}), 1070.4(\mathrm{C}-\mathrm{O}-\mathrm{C})$.

\section{Adipic acid dihydrazide 3}

A mixture of diethyl adipate $2(5 \mathrm{~g}, 0.028 \mathrm{~mol})$ and an excess of hydrazine hydrate $(0.05 \mathrm{~mol})$ in absolute ethanol $(150 \mathrm{~mL})$ were refluxed for 6 hours on a water bath. The purity of the products was checked by single spot TLC, the reaction mixture was cooled. Then the solvent was evaporated under reduced pressure to give adipic acid dihydrazide 3. Yield- 67\%. Powder, m.p. $180-181^{\circ} \mathrm{C}, \mathrm{R} f=0.40\left(\mathrm{CHCl}_{3} / \mathrm{CH}_{3} \mathrm{OH}=9 / 1\right)$; IR $\left(\mathrm{KBr}, v \mathrm{~cm}^{-1}\right): 3222.8\left(\mathrm{NH}^{-\mathrm{NH}}\right), 1606.6$ $(\mathrm{C}=\mathrm{O}) .{ }^{1} \mathrm{H}-\mathrm{NMR}: 8.34\left(3 \mathrm{H}, \mathrm{O}=\mathrm{C}-\mathrm{N} \underline{H N}_{2}\right), 1.99\left(2 \mathrm{H}, \mathrm{O}=\mathrm{C}-\mathrm{C}_{2} \underline{\mathrm{CH}}_{2}\right), 1.42\left(2 \mathrm{H}, \mathrm{O}=\mathrm{C}-\mathrm{CH}_{2} \underline{\mathrm{H}}_{2}\right) .{ }^{13} \mathrm{C}-\mathrm{NMR}: 178.2$ $\left(\mathrm{O}=\underline{\mathbf{C}}-\mathrm{NHNH}_{2}\right), 39.8\left(\mathrm{O}=\mathrm{C}-\underline{\mathrm{C}} \mathrm{H}_{2} \mathrm{CH}_{2}\right), 26.3\left(\mathrm{O}=\mathrm{C}-\mathrm{CH}_{2} \underline{\mathbf{C}} \mathrm{H}_{2}\right)$.

2,2'-butane-1,4-diylbis[5-(bromomethyl)-1,3,4-oxadiazole] (4). A mixture of adipic acid dihydrazide 3 (3g, 0.017 mol), bromoacetic acid $(4.78 \mathrm{~g}, 0.034 \mathrm{~mol})$ and phosphours oxychloride $(5 \mathrm{~mL})$ was refluxed at $80-90^{\circ} \mathrm{C}$ for 6 hours. After completion of reaction, as indicated by TLC, the mixture was cooled and poured into ice water and then sodium bicarbonate solution was added. The resulting solid was collected by filtration, washed with cold water, and dried. Then the solvent was evaporated under reduced pressure to give 2,2'-butane-1,4-diylbis[5-(bromomethyl)-1,3,4-oxadiazole] 4. Yield- $85 \%$. Crystalline solid, m.p. $114-115^{\circ} \mathrm{C}, \mathrm{R} f=0.42\left(\mathrm{CHCl}_{3} / \mathrm{CH}_{3} \mathrm{OH}=4 / 1\right) ; \mathrm{IR}\left(\mathrm{KBr}, v \mathrm{~cm}^{-1}\right): 1643.2(\mathrm{C}=\mathrm{N})$, 1105.1(C-O-C), 497(C-Br). ${ }^{1} \mathrm{H}-\mathrm{NMR}: 8.30\left(2 \mathrm{H}, \mathrm{O}=\mathrm{C}-\underline{\mathrm{CH}}_{2}-\mathrm{Br}\right), 2.17\left(2 \mathrm{H}, \mathrm{N}=\mathrm{C}-\mathrm{C}_{2} \mathrm{CH}_{2}\right), 1.45\left(2 \mathrm{H}, \mathrm{N}=\mathrm{C}-\mathrm{CH}_{2} \mathrm{C} \underline{\mathbf{H}}_{2}\right)$. ${ }^{13} \mathrm{C}-\mathrm{NMR}: 174.8\left(\mathrm{~N}=\underline{\mathbf{C}}-\mathrm{CH}_{2} \mathrm{CH}_{2}\right), 172.1\left(\mathrm{O}=\underline{\mathbf{C}}-\mathrm{CH}_{2}-\mathrm{Br}\right), 39.7\left(\mathrm{~N}=\mathrm{C}-\underline{\mathbf{C}} \mathrm{H}_{2} \mathrm{CH}_{2}\right), 33.8\left(\mathrm{~N}=\mathrm{C}-\mathrm{CH}_{2} \underline{\mathbf{C H}}_{2}\right), 24.4\left(\mathrm{O}=\mathrm{C}^{-\underline{\mathbf{C}}} \mathrm{H}_{2}\right.$ $\mathrm{Br})$.

N,N'-[butane-1,4-diylbis(1,3,4-oxadiazole-5,2-diylmethylene)]bis[N,N-diethyl-2-(methacryloyloxy)ethan ammonium] bromide (5a). According to the procedure adopted by Guiqian Lu et al. [38], a mixture of compound 4 $(1 \mathrm{~g}, 0.003 \mathrm{~mol})$ and tertiary amine DEAEMA $(0.97 \mathrm{~g}, 0.005 \mathrm{~mol})$ was dissolved in dry acetone $(50 \mathrm{~mL})$, in the presence of hydroquinone. The mixture was gently refluxed for 40 hours on water bath. After cooling, diethyl ether was added, the target diquaternary ammonium salt 5 a was collected by filtration under reduced pressure and washed several times with diethyl ether. Yield- 82\%. Pasty mass, $\mathrm{R} f=0.50\left(\mathrm{CHCl}_{3} / \mathrm{CH}_{3} \mathrm{OH}=4 / 1\right)$; $\mathrm{IR}\left(\mathrm{KBr}, \mathrm{v} \mathrm{cm}^{-1}\right): 1737.7(\mathrm{C}=\mathrm{O}), 1625.9$ $(\mathrm{C}=\mathrm{N}), 1460(\mathrm{C}=\mathrm{C}), 1026.1(\mathrm{C}-\mathrm{O}-\mathrm{C}) .{ }^{1} \mathrm{H}-\mathrm{NMR}: 6.12-5.76\left(2 \mathrm{H},{ }^{=} \underline{\mathrm{H}}_{2}\right), 4.44\left(2 \mathrm{H}, \mathrm{N}^{+} \mathrm{CH}_{2} \mathrm{C}_{2}\right), 3.73\left(2 \mathrm{H}, \mathrm{N}=\mathrm{C}-\mathrm{C} \underline{\mathbf{H}}_{2}\right.$ $\left.\mathrm{N}^{+}\right), 3.44\left(2 \mathrm{H}, \mathrm{N}^{+} \underline{\mathrm{H}}_{2} \mathrm{CH}_{2}\right), 2.55\left(3 \mathrm{H}, \mathrm{N}^{+} \mathrm{CH}_{3}\right), 1.93\left(2 \mathrm{H}, \mathrm{N}=\mathrm{C}-\underline{\mathrm{H}}_{2} \underline{\mathrm{CH}}_{2}\right), 1.49\left(3 \mathrm{H}, \mathrm{C}\left(\mathrm{CH}_{3}\right)=\mathrm{CH}_{2}\right), 1.23(2 \mathrm{H}, \mathrm{N}=\mathrm{C}-$ $\left.\mathrm{CH}_{2} \underline{\mathrm{H}}_{2}\right) \cdot{ }^{13} \mathrm{C}-\mathrm{NMR}: 174.0\left(\mathrm{~N}=\underline{\mathbf{C}}-\mathrm{CH}_{2} \mathrm{CH}_{2}\right), 166.5(\underline{\mathbf{C}}=\mathrm{O}), 157.0\left(\mathrm{~N}=\underline{\mathbf{C}}-\mathrm{CH}_{2} \mathrm{~N}^{+}\right), 136.0\left(\underline{\mathbf{C}}\left(\mathrm{CH}_{3}\right)=\mathrm{CH}_{2}\right), 125.6\left(=\underline{\mathbf{C}} \mathrm{H}_{2}\right)$, $63.3\left(\mathrm{~N}^{+} \underline{\mathbf{C H}}_{2} \mathrm{CH}_{2}\right) 55.7\left(\mathrm{~N}=\mathrm{C}-\underline{\mathrm{CH}}_{2} \mathrm{~N}^{+}\right), 50.6\left(\mathrm{~N}^{+} \mathrm{CH}_{2} \underline{\mathrm{CH}}_{2}\right), 47.2\left(\mathrm{~N}^{+} \underline{\mathrm{CH}}_{3}\right), 26.7\left(\mathrm{~N}=\mathrm{C}_{-} \underline{\mathrm{CH}}_{2} \mathrm{CH}_{2}\right), 24.4\left(\mathrm{~N}=\mathrm{C}-\mathrm{CH}_{2} \underline{\mathbf{C}} H_{2}\right)$, $17.8\left(\mathrm{C}\left(\mathrm{CH}_{3}\right)=\mathrm{CH}_{2}\right)$.

N,N'-[butane-1,4-diylbis(1,3,4-oxadiazole-5,2-diylmethylene)]bis[2-(methacryloyloxy)-N,N-dimethylethan ammoinium] bromide (5b). Compound $4(1 \mathrm{~g}, 0.003 \mathrm{~mol})$ was dissolved in dry acetone $(40 \mathrm{~mL})$ and the resulting solution was mixed with DMAEMA $(0.81 \mathrm{~g}, 0.005 \mathrm{~mol})$, in the presence of hydroquinone. The mixture was gently refluxed for 40 hours on water bath. After completion of the reaction, the solvent was evaporated and the formed precipitate was filtered, washed with diethyl ether and dried. Yield of compound 5b- 79\%. Pasty mass, $\mathrm{R} f=0.58\left(\mathrm{CHCl}_{3} / \mathrm{CH}_{3} \mathrm{OH}=4 / 1\right)$; IR (KBr, v cm $\left.{ }^{-1}\right): 1737.7(\mathrm{C}=\mathrm{O}), 1647.1(\mathrm{C}=\mathrm{N}), 1460(\mathrm{C}=\mathrm{C}), 1022.2(\mathrm{C}-\mathrm{O}-\mathrm{C}) .{ }^{1} \mathrm{H}-\mathrm{NMR}: 6.17-5.75\left(2 \mathrm{H},=\mathrm{C} \underline{\mathbf{H}}_{2}\right), 4.40$ $\left(2 \mathrm{H}, \mathrm{N}^{+} \mathrm{CH}_{2} \underline{\mathrm{CH}}_{2}\right), 3.71\left(2 \mathrm{H}, \mathrm{N}=\mathrm{C}-\mathrm{CH}_{2} \mathrm{~N}^{+}\right), 3.39\left(2 \mathrm{H}, \mathrm{N}^{+} \underline{\mathrm{C}}_{2} \mathrm{CH}_{2}\right), 2.78\left(3 \mathrm{H}_{,} \mathrm{N}^{+} \underline{\mathrm{C}}_{3}\right), 2.50\left(2 \mathrm{H}, \mathrm{N}=\mathrm{C}-\mathrm{C} \underline{\mathbf{H}}_{2} \underline{\mathrm{CH}}_{2}\right), 1.90$ $\left(3 \mathrm{H}, \mathrm{C}\left(\mathrm{CH}_{3}\right)=\mathrm{CH}_{2}\right), 1.14\left(2 \mathrm{H}, \mathrm{N}=\mathrm{C}-\mathrm{CH}_{2} \underline{\mathrm{C}}_{2}\right) \cdot{ }^{13} \mathrm{C}-\mathrm{NMR}: 174.9\left(\mathrm{~N}=\underline{\mathbf{C}}-\mathrm{CH}_{2} \mathrm{CH}_{2}\right), 167.0(\underline{\mathbf{C}}=\mathrm{O}), 155.67\left(\mathrm{~N}=\underline{\mathbf{C}}-\mathrm{CH}_{2} \mathrm{~N}^{+}\right)$, $136.0\left(\underline{\mathbf{C}}\left(\mathrm{CH}_{3}\right)=\mathrm{CH}_{2}\right), 128.0\left(=\underline{\mathbf{C}} H_{2}\right), 62.3\left(\mathrm{~N}^{+} \underline{\mathbf{C H}}_{2} \mathrm{CH}_{2}\right), 59.0\left(\mathrm{~N}=\underline{\mathrm{C}}-\underline{\mathbf{C}} \mathrm{H}_{2} \mathrm{~N}^{+}\right), 50.1\left(\mathrm{~N}^{+} \mathrm{CH}_{2} \underline{\mathbf{C H}}_{2}\right), 43.1\left(\mathrm{~N}^{+} \underline{\mathbf{C}} \mathrm{H}_{3}\right), 27.1$ $\left(\mathrm{N}=\mathrm{C}-\underline{\mathrm{CH}}_{2} \mathrm{CH}_{2}\right), 24.3\left(\mathrm{~N}=\mathrm{C}-\mathrm{CH}_{2} \underline{\mathrm{C}} \mathrm{H}_{2}\right), 17.8\left(\mathrm{C}\left(\mathrm{CH}_{3}\right)=\mathrm{CH}_{2}\right)$.

\section{Testing the biological activity}

Determination of minimum inhibitory concentration (MIC)

MIC of the synthesized compounds 3, 4, 5a and $\mathbf{5 b}$ was determined by using the broth microdilution method [39]. The solutions of each tested compounds were prepared in DMSO to get a concentration of $100 \mathrm{mg} / \mathrm{mL}$. From this stock solution, serial dilutions of the compounds (100, 50, 25, 12.5, 6.25, 3.12, 1.56, 0.78, 0.39, 0.19, and 0.097 mg/mL) were prepared. The MIC was recorded in each case as the minimum concentration of the compound, which inhibited the visible growth of the tested microorganism, and DMSO was used as a negative control.

\section{Antibacterial activity}

In order to evaluate the antibacterial activity eleven bacteria have been used: Enterobacter aerogenes (ATCC 51697), Citrobacter freundii (ATCC 8090), Acetobacter aceti (ATCC 15973), Escherichia coli (ATCC 25933), Klebsiella 
pneumoniae (ATCC 70603), Enterobacter cloacae (ATCC 13047), Pseudomonas aeruginosa (ATCC 27853) and Salmonella enterica (ATCC 13312) as gram negative bacteria and Methicillin-resistant Staphylococcus aureus (MRSA) (ATCC 43300), Curtobacterium flaccumfaciens (ATCC 53934) and Staphylococcus wavy as gram positive bacteria.

All microorganisms were obtained from Microbiology Laboratory, Institute of Biology, University of Dr. Moulay Tahar, Saïda. The bacterial strains were maintained on Muller-Hinton agar and the tested compounds were dissolved in DMSO to make a stock solution of $100 \mathrm{mg} / \mathrm{mL}$ and the other concentrations were prepared by dilution. A suspension of the organisms was introduced onto the surface of sterile agar plates, and then incubated at $37{ }^{\circ} \mathrm{C}$ for $18-$ $24 \mathrm{hrs}$. After incubation, MIC was determined. All the tests were performed in triplicate.

\section{Antifungal activity}

Antifungal activity has been tested on three pathogenic fungi of tomato, such as Fusarium oxysporum MIAE 00123, Fusarium commune MIAE 00112 and Fusarium rodelens MIAE 00129 by the diffusion plate method [40].

All the fungal strains were obtained from collection of pure cultures of the laboratory of Applied Microbiology Faculty of Nature Sciences and Life, Oran University, Algeria. The test compounds were dissolved in DMSO (1 mL), mixed with potato dextrose agar PDA at concentrations of 50,100, 150 and $200 \mu \mathrm{g} / \mathrm{mL}$ and poured onto sterile Petri dishes (with diameter of $9 \mathrm{~cm}$ ). A $6 \mathrm{~mm}$ disc containing mycelia was transferred to the center of PDA plate. Tree replications were maintained for each concentration and DMSO was used as a control solvent. Then the inoculated plates were incubated at $37^{\circ} \mathrm{C}$ for 4 days and the zone of inhibition was observed and measured. The relative inhibition rate of the circle mycelium compared to blank assay was calculated via the following equation:

Relative inhibition rate $(\%)=[(T-C) / T] \times 100 \%$

where: $T$ is the extended diameter of the circle mycelium during the blank assay,

$C$ is the extended diameter of the circle mycelium during testing.

\section{Results and discussion}

\section{Chemistry}

The target compounds $\mathbf{5 a}$ and $\mathbf{5 b}$ were synthesized by a multiple-step procedure as shown in Figure 1 . The synthetic route started from esterfication of adipic acid 1 using ethanol in the presence of sulphuric acid. This ester reacted with hydrazine hydrate in ethanol to give adipic acid dihydrazide 3. Bis-1,3,4-oxadiazole 4 was obtained by ring closure reaction upon treating acid hydrazide 3 with bromoacetic acid in phosphorus oxychloride. Finally, the products $\mathbf{5 a}$ and $\mathbf{5 b}$ were obtained by refluxing compound $\mathbf{4}$ with the appropriate tertiary amine (DEAEMA or DMAEMA) in acetone to give the corresponding quaternary ammonium salts.

The physiochemical data of the synthesized compounds (2-4, 5a and $\mathbf{5 b})$ are presented in Table 1 . The percentage yield of all the synthesized compounds was found to be in the range of $67-85 \%$.

The purity of the synthesized compounds was checked by thin layer chromatography and melting points values. The structures of all the synthesized compounds were confirmed by IR, ${ }^{1} \mathrm{H}$ and ${ }^{13} \mathrm{C}$ NMR spectral data.<smiles>[R][N+]([R])([R])Cc1nnc(C(C)(C)c2nnc(C[N+]([R])([R])Br)o2)o1</smiles><smiles>[R]CCOC(=O)C(=C)C</smiles>

Figure 1. Synthetic route of the final compounds $5 a-b$.

Reagents and conditions: (i) $\mathrm{C}_{2} \mathrm{H}_{5} \mathrm{OH}$ and conc. $\mathrm{H}_{2} \mathrm{SO}_{4}$, reflux for $8 \mathrm{~h}$; (ii) $\mathrm{NH}_{2} \mathrm{NH}_{2}-\mathrm{H}_{2} \mathrm{O}, \mathrm{C}_{2} \mathrm{H}_{5} \mathrm{OH}$, reflux for $5 \mathrm{~h}$; (iii) $\mathrm{POCl}_{3}, \mathrm{BrCH}_{2} \mathrm{COOH}$, reflux for $6 \mathrm{~h}$; (iv) DMAEMA/DEAEMA, acetone, reflux for $40 \mathrm{~h}$. 
Physical properties and analytical data of the synthesized compounds.

\begin{tabular}{cccccc}
\hline Compound & Colour & $\begin{array}{c}\text { Yield, } \\
\%\end{array}$ & $\begin{array}{c}\text { Melting point, } \\
{ }^{\circ} \mathrm{C}\end{array}$ & $\begin{array}{c}\text { Rf value } \\
\text { Solvent system } \\
\mathrm{CHCl}_{3} / \mathrm{CH}_{3} \mathrm{OH}\end{array}$ \\
\hline $\mathbf{2}$ & Colorless & 76 & liquid & 0.45 & $8 / 2$ \\
$\mathbf{3}$ & White & 67 & $180-181$ & 0.40 & $4 / 1$ \\
$\mathbf{5}$ & White & 85 & $114-115$ & 0.42 & $4 / 1$ \\
$\mathbf{5 b}$ & Brown & 82 & semi-solide & 0.50 & $4 / 1$ \\
\hline
\end{tabular}

\section{Biological activity}

Antibacterial activity

The synthesized compounds have been tested in vitro for their antibacterial activity against eleven bacteria, such as Enterobacter aerogenes ATCC 51697, Citrobacter freundii ATCC 8090, Acetobacter aceti, Escherichia coli, Klebsiella pneumoniae, Enterobacter cloacae, Pseudomonas aeruginosa and Salmonella enterica ATCC 13312 as gram negative bacteria and Methicillin-resistant Staphylococcus aureus (MRSA) ATCC 43300, Curtobacterium flaccumfaciens and Staphylococcus wavy as gram positive bacteria. The obtained results are summarized in Table 2.

Table 2

Minimal inhibitory concentration in $\mathrm{mg} / \mathrm{mL}$ of synthesized compounds against tested bacterial strains by microdilution method.

\begin{tabular}{lcccc}
\hline \multicolumn{1}{c}{ Strains } & \multicolumn{3}{c}{ Compound and values of MIC in $\mathrm{mg} / \mathrm{mL}$} \\
\cline { 2 - 5 } & $\mathbf{3}$ & $\mathbf{4}$ & $\mathbf{5 a}$ & $\mathbf{5 b}$ \\
\hline Enterobacter aerogenes (ATCC 51697) & 0.097 & 12.5 & 25 & 12.5 \\
Citrobacter freundii (ATCC 8090) & 12.5 & 0.39 & 0.19 & 0.097 \\
Acetobacter aceti (ATCC 15973) & 1.56 & 6.25 & 6.25 & 6.25 \\
Escherichia coli (ATCC 25933) & 6.25 & 1.56 & 100 & 50 \\
Klebsiella pneumoniae (ATCC 70603) & 6.25 & 0.78 & 25 & 25 \\
Enterobacter cloacae (ATCC 13047) & 3.12 & 12.5 & 12.5 & 12.5 \\
Pseudomonas aeruginosa (ATCC 27853) & 3.12 & 12.5 & 12.5 & 12.5 \\
Salmonella enterica (ATCC 13312) & 0.78 & 12.5 & 12.5 & 12.5 \\
Methicillin-resistant Staphylococcus aureus (MRSA) & 25 & 0.78 & 0.78 & 0.78 \\
ATCC 43300) & & & & \\
Curtobacterium flaccumfaciens (ATCC 53934) & 3.12 & 12.5 & 25 & 25 \\
Staphylococcus wavy & 1.56 & 12.5 & 12.5 & 25 \\
\hline
\end{tabular}

As it is shown in Table 2, the results of evaluating the antibacterial properties suggest that all compounds have very good potential to act as antibacterial agents. The values of MIC ranged between: 0.097-100 mg/mL. Compounds $\mathbf{3}$ and $\mathbf{4}$ have shown the highest antibacterial activity against all tested microorganisms. The best activity was observed against Citrobacter freundii ATCC 8090 and MRSA by compound $\mathbf{5 a}$ and $\mathbf{5 b}$, but relatively low antibacterial activity (MIC 50-100 $\mu \mathrm{g} / \mathrm{mL}$ ) was observed against Escherichia coli.

\section{Antifungal activity}

Similarly, the newly prepared compounds were screened in vitro for their antifungal activity against three pathogenic fungi of tomato, such as Fusarium oxysporum MIAE 00123, Fusarium commune MIAE 00112 and Fusarium rodelens MIAE 00129. The results of in vitro antifungal activities are presented in Table 3 . The antifungal screening showed that the maximum inhibitory activity was found for compound $\mathbf{3}$ against all of tested fungi at concentration of $200 \mu \mathrm{g} / \mathrm{mL}$, and compound $\mathbf{4}$ showed good activity against the tested fungi, compound $\mathbf{5 a}$ and $\mathbf{5 b}$, showed moderate activity against Fusarium oxysporum and Fusarium rodelens. However, lower activity was observed for compound $\mathbf{5 b}$ against Fusarium commune.

Table 3

Relative inhibition rate (\%) of synthesized compounds against tested fungal strains.

\begin{tabular}{|c|c|c|c|c|c|c|c|c|c|c|c|c|}
\hline \multirow{4}{*}{ Compound } & \multicolumn{12}{|c|}{ Relative inhibition rate (\%) } \\
\hline & \multicolumn{4}{|c|}{ Fusarium oxysporum } & \multicolumn{4}{|c|}{ Fusarium commune } & \multicolumn{4}{|c|}{ Fusarium rodelens } \\
\hline & \multicolumn{12}{|c|}{ Concentration in $\mu \mathrm{g} / \mathrm{mL}$} \\
\hline & 50 & 100 & 150 & 200 & 50 & 100 & 150 & 200 & 50 & 100 & 150 & 200 \\
\hline 3 & 14.5 & 15.5 & 16.6 & 18.8 & 3.3 & 12.2 & 21.1 & 22.2 & 6.6 & 8.8 & 30 & 30 \\
\hline 4 & 12.2 & 12.9 & 13.3 & 15.5 & 10 & 11.1 & 11.1 & 11.1 & 7.7 & 8.8 & 11.1 & 11.1 \\
\hline $5 a$ & 5.5 & 6.6 & 6.6 & 7.7 & 3.3 & 5.5 & 6.6 & 6.6 & 6.6 & 6.6 & 7.7 & 8.8 \\
\hline $5 \mathbf{b}$ & 5.5 & 5.5 & 7.4 & 14.4 & 1.1 & 1.1 & 3.3 & 4.4 & 5.5 & 6.6 & 7.7 & 7.7 \\
\hline
\end{tabular}




\section{Conclusions}

The present study reports on the successful synthesis and antimicrobial activity of some novel bis-1,3,4-oxadiazole compounds containing quaternary ammoniums salt moiety. The 1,3,4-oxadiazole heterocycle was synthesized by ring-closing reaction, and quaternary ammonium salt was obtained by $N$-alkylation. All the synthesized compounds were structurally characterized using IR and NMR spectroscopic techniques. The newly synthesized compounds were evaluated for their antibacterial and antifungal activity. The results of biological tests indicated that most of the synthesized compounds exhibited promising results. Thus, the mixed compounds containing both 1,3,4-oxadiazole and quaternary ammonium salts moieties can serve as interesting lead molecules for further synthetic and biological evaluation.

\section{Acknowledgments}

The authors are grateful to Mrs HIDOUR Hanaa (University of Oran, Es-Senia) for recording the NMR spectra.

\section{References}

1. Rodrigo, S.; Lisa, R.; Michael, B.; Teresa, Z.; Wanseon, L.; Duccio, C.; Luigina, R.; Brian, M.; Ivo, G.; Manuel, S.; Philippe, P.; Paul, B.; Misha, K. Systems biology of infectious diseases: a focus on fungal infections. Immunobiology, 2011, 216, pp. 1212-1227.

2. Gharamah, A.A.; Moharram, A.M.; Ismail, M.A.; Al-Hussaini, A.K. Bacterial and fungal endophthalmitis in upper Egypt: related species and risk factors. Asian Pacific Journal of Tropical Biomedicine, 2012, 2(8), pp. 655-659.

3. Kawecki, D.; Kwiatkowski, A.; Sawicka, G.A.; Durlik, M.; Mlynarczyk G.; Chmura, A. Bacterial and fungal infections in the early post-transplantation period after simultaneous pancreas-kidney transplantation: etiological agents and their susceptibility.Transplant Proceedings, 2014, 46(8) , pp. 2802-2805.

4. Garba, I.; Farouq, M.D.; Tiamiyu, A.B.; Zaiyad, G.H.; Isa, M.T.; Abdulrazaq, G.H. Pattern of antibiotic prescription and resistance profile of common bacterial isolates in the internal medicine wards of a tertiary referral centre in Nigeria. Journal of Global Antimicrobial Resistance, 2015, 3, pp. 91-94.

5. Kevin, K.C.L.; Subas, M.S.; Christopher, J.O.; Andrew, C.F.; Hong, X.D. Synthetic approaches to the 2010 new drugs. Bioorganic \& Medicinal Chemistry, 2012, 20, pp. 1155-1174.

6. Kevin, B.P.; Emma, D.B.; Charlotte, H.; Dominic, P.W. Selection of new chemical entities with decreased potential for adverse drug reactions. European Journal of Pharmacology, 2006, 549(1-3), 7, pp. 1-8.

7. Hong, X.D.; Carolyn, A.L.; Robert, E.K.J.; Kevin, K.C.L.; Sarah, J.F.; Andrew C.F.; Christopher J.O. Synthetic approaches to the 2013 new drugs. Bioorganic \& Medicinal Chemistry, 2015, 23, pp. 1895-1922.

8. Mouhssen L. The Success of Natural Products in Drug Discovery. Pharmacology \& Pharmacy, 2013, 4, pp. 17-31.

9. Vanessa, L.C.; Daniel, F.K.; Dílson, B.S.J.; Ivone, C. Carrageenans: biological properties, chemical modifications and structural analysis-A review. Carbohydrate Polymers, 2009, 77, pp. 167-180.

10. Kavitha, S.; Gnanavel, S.; Kannan, K. Biological aspects of 1,3,4-oxadiazole derivatives. Asian Journal of Pharmaceutical and Clinical Research, 2014, 7(4), pp.11-20.

11. Musmade, D.S.; Pattan, S.R.; Manjunath, S.Y. Oxadiazole a nucleus with versatile biological behaviour. International Journal of Pharmaceutical Chemistry, 2015, 5(1), pp. 11-20.

12. Sumit, B.; Manju, B.; Sharad, K.S.; Shivani, C.; Shoumyo, B.; Varun, B.; Sumit, S.; Alex, J. Design and synthesis of novel 2-phenyl-5-(1,3-diphenyl-1H-pyrazol-4-yl)-1,3,4-oxadiazoles as selective COX-2 inhibitors with potent anti-inflammatory activity. European Journal of Medicinal Chemistry, 2014, 80, pp. 167-174.

13. Shivi, B.; Monika, G. 1,3,4-Oxadiazole as antimicrobial agents: An overview. Journal of Chemical and Pharmaceutical Research, 2011, 3(3), pp. 137-147.

14. Abbas, S.; Mohammad, A.; Amir, N.; Nasir, S.; Nasim, V.; Sayyed, A.T.; Reza, K. Synthesis and analgesic activity of new 1,3,4-oxadiazoles and 1,2,4-triazoles. Medicinal Chemistry Research, 2011, 20(4), pp. 435-442.

15. Li, Z.; Zhan P.; Liu X. 1,3,4-Oxadiazole: A privileged structure in antiviral agents. Mini-Reviews in Medicinal Chemistry, 2011, 11, pp. 1130-1142.

16. Gamal El-Din, M.M.; El-Gamal, M.I.; Abdel-Maskoud, M.S.; Yoo, K.H.; Oh, C.H. Synthesis and broad-spectrum antiproliferative activity of diarylamides and diarylureas possessing 1,3,4-oxadiazole derivatives. Bioorganic \& Medicinal Chemistry Letters, 2015, 25(8), pp. 1692-1699.

17. Kai, Z.; Peng, W.; Li-Na, X.; Xiao Y.F.; Fen, J.; Sha, L.; Yu-Ming, L.; Bao-Quan, C. Synthesis and antitumor activities of novel hybrid molecules containing 1,3,4-oxadiazole and 1,3,4-thiadiazole bearing Schiff base Moiety. Bioorganic \& Medicinal Chemistry Letters, 2014, 24(22), pp. 5154-5156.

18. Bankar, G.R.; Nandakumar, K.; Nayak, P.G.; Thakur, A.; Chamallamudi, M.R.; Nampurath, G.K. Vasorelaxant effect in rat aortic rings through calcium channel blockage: A preliminary in vitro assessment of a 1,3,4-oxadiazole derivative. Chemico-Biological Interactions, 2009, 181, pp. 377-382.

19. Vardan, S.; Mookherjee, S.; Eich, R. Effects of tiodazosin, a new antihypertensive, hemodynamics and clinical variables. Clinical Pharmacology \& Therapeutics, 1983, 34(3), pp. 290-296. 
20. Liang, M.; Yu, X.; Cong, L.; Zheng-Lu, X.; Dong-Dong, L.; Yan-Ting, W.; Hai-Tian, M.; Hai-Liang, Z.; MingHua, W.; Yong-Hao, Y. Synthesis and antioxidant activity of novel Mannich base of 1,3,4-oxadiazole derivatives possessing 1,4-benzodioxan. Bioorganic \& Medicinal Chemistry, 2013, 21, pp. 6763-6770.

21. Somani, R.R.; Balkund, V.D.; Nikam, S.R.; Shirodkar, P.Y.; Zope, D.B. Synthesis, antibacterial and anti-tubercular evaluation of some 1,3,4-oxadiazole based Mannich bases. International Journal of ChemTech Research, 2013, 5(5), pp. 2588-2592.

22. Sayyed, A.T.; Elham, R.Z.; Hamed, R.; Bagher, A.; Bijan, S.; Majid, S.; Abbas, S.; Mehrdad, F. Evaluation of anxiolytic, sedative-hypnotic and amnesic effects of novel 2-phenoxy phenyl-1,3,4-oxadizole derivatives using experimental models. Iran Journal of Pharmaceutical Research, 2015, 14, pp. 51-57.

23. Deepak, S.; Rakshit, A.; Ritu, V. Microwave-assisted synthesis of some 1,3,4-oxadiazole derivatives and evaluation of their antibacterial and antifungal activity. Organic Chemistry International. Volume 2014, Article ID 694060. http://dx.doi.org/10.1155/2014/694060.

24. Dörwald, F.Z. Lead Optimization for Medicinal Chemists: Pharmacokinetic Properties of Functional Groups and Organic Compounds. John Wiley \& Sons: New York, 2013, pp. 118-119.

25. Xiaoshuai, Q.; Yancai, L.; Fang, Z.; Lixia, R.; Yunhui, Z.; Xiaoyan, Y. Polydimethylsiloxane-polymethacrylate block copolymers tethering quaternary ammonium salt groups for antimicrobial coating. Applied Surface Science, 2015, 328, pp. 183-192.

26. Sauvet, G.; Dupond, S.; Kazmierski, K.; Chojnowski, J. Biocidal polymers active by contact. V. Synthesis of polysiloxanes with biocidal activity. Journal of Applied Polymer Science, 2000, 75, pp. 1005-1012.

27. Domagk, G. A new class of disinfectant. Deutsche Medizinische Wochenscherift, 1935, 61(21), pp. 829-832, (in German).

28. Jeffrey, G.L.; Peter, N.C.; Preston, A.F.; James, H.W. Relationship between surface concentration of amphiphilic quaternary ammonium biocides in electrospun polymer fibers and biocidal activity. Reactive \& Functional Polymers, 2014, 77, pp. 39-46.

29. Anqiang, Z.; Qiongqiong, L.; Yufeng, L.; Shuanghao, H.; Yaling, L. Synthesis and antimicrobial activities of acrylamide polymers containing quaternary ammonium salts on bacteria and phytopathogenic fungi. Reactive \& Functional Polymers, 2015, 88, pp. 39-46.

30. Chamari, W.; Marianna, B.; Lívia, B.; Magdolna, E.S.; Ilona, P. Optimization of liposomal encapsulation for ceftazidime for developing a potential eye drop formulation. Journal of Basic and Clinical Pharmacy, 2013, 4(3), pp. 73-75.

31. Ulas, T.; Spyros, G.P. Quaternary ammonium disinfectants: Microbial adaptation, degradation and ecology. Current Opinion in Biotechnology, 2015, 33, pp. 296-304.

32. Nicoletta, B.; Mara, M.; Denise, P.; Donatella, T.; Riccardo, S.; Elena, P. Modified quaternary ammonium salts as potential antimalarial agents. Bioorganic \& Medicinal Chemistry, 2015, 23, pp. 4681-4687.

33. Yaling, L.; Qiongqiong, L.; Liujun, C.; Yufeng, L.; Anqiang, Z. Synthesis and antimicrobial activities of polysiloxanecontaining quaternary ammonium salts on bacteria and phytopathogenic fungi. Reactive \& Functional Polymers, 2014, 85, pp. 36-44.

34. Xu, Z.S.; Ning, W.; Di, C.; Zi, Y.H.; Pu, M.; Hai, B.Z.; Xiao, H.Z. The antimicrobial activities of a series of bisquaternary ammonium compounds. Chinese Chemical Letters, 2011, 22, pp. 887-890.

35. Yashumati, R.B.; Ashutosh, P.; Vivek, J.; Dharma, K.; Chemical delivery systems and soft drugs: Retrometabolic approaches of drug design. Saudi Pharmaceutical Journal, 2014, 22, pp. 290-302.

36. Guo-Qiang, H.; Li-Li, H.; Guo-Qiang, W.; Nan-Nan, D.; Xiao-Yi, W.; Tie-Yao, C.; Jun, Y.; Wei, W.; SongQiang, X.; Wen-Long, H. Part IV: design, synthesis and antitumor activity of fluoroquinolone C-3 heterocycles: bis-oxadiazole methylsulfide derivatives derived from ciprofloxacin. Acta Pharmaceutica Sinica, 2012, 47(8), pp. 1017-1022.

37. Furniss, B.S.; Hannford, A.J.; Smith, P.W.G.; Tatchell, A.R. Vogel's Text Book of Practical Organic Chemistry. John Wiley \& Sons: New York, 5th edition, 1989, pp. 1076.

38. Guiqian, L.; Dingcai, W.; Ruowen, F. Studies on the synthesis and antibacterial activities of polymeric quaternary ammonium salts from dimethylaminoethyl methacrylate. Reactive \& Functional Polymers, 2007, 67, pp. 355-366.

39. Reference method for broth dilution antifungal susceptibility testing of yeasts, Approved Standard, $2^{\text {nd }}$ Edition, Clinical and Laboratory Standards Institute (USA), NCCLS document M27-A2, 2002, 22(15), 51p.

40. Hamini, K.N.; Hamdane, F.; Boutoutaou, R.; Kihal, M.; Henni, J.E. Antifungal activity of clove (Syzygium aromaticum L.) Essential oil against phytopathogenic fungi of tomato (Solanum lycopersicum L.) in Algeria. Journal of Experimental Biology and Agricultural Sciences, 2014, 2(5), pp. 448-454. 